\title{
The Effectiveness of VCO (Virgin Coconut Oil) in People with Obesity in the Working Area of Public Health Bontonyeleng
}

\author{
Nadia Alfira ${ }^{1}$, Muriyati ${ }^{1}$, A. Tenri Fajriani ${ }^{2}$, Asri $^{1 *}$ \\ ${ }^{1}$ Department of Nursing, Stikes Panrita Husada Bulukumba, Indonesia \\ ${ }^{2}$ Department of Midwifery, Stikes Panrita Husada Bulukumba, Indonesia \\ *Corresponding Author \\ Asri
}

\author{
Article History \\ Received: 04.03.2021 \\ Accepted: 22.03.2021 \\ Published: 21.04.2021
}

\begin{abstract}
Background: Obesity is a condition in which body fat is in an excessive amount. Obesity is the 5th leading cause of death in the world. About 2.8 million people worldwide die from complications of obesity, $23 \%$ suffer from ischemic heart disease, and $7 \%$ to $41 \%$ have a risk of developing cancer in certain organs. In Bulukumba Regency (2016), the prevalence of obesity was 913 people (49.3\%). As many as 115 men (7.21\%), 798 women (50.03\%) who were gathered from several health centers. There are 13 health centers that have not collected data on obesity, one of which is the Bontonyeleng Health Center. Research Objectives to determine the effectiveness of VCO (Virgin Coconut Oil in people with obesity in the working area of Bontonyeleng Community Health Center, Taccorong Village, Gantarang District, Bulukumba Regency. Research methodology The research design used two groups, by conducting one pre-test) treatment (treatment) and after that measurement again (post-test). The population in this study, people with obesity. The sample is 30 people. Research Results The results showed that the median in the group given VCO intervention was lower than before VCO intervention was given. This indicates a decrease in BMI results. The results of statistical tests (Wilcoxon test) show ap value: $0.013(\mathrm{p}<0.05)$ means that Ho is rejected, meaning that statistically, there is a significant effect of VCO intervention on BMI reduction in obese people in the work area bontonyeleng puskesmas Conclusion IMT measurement The sample is 30 people. Research Results The results showed that the median in the group given VCO intervention was lower than before VCO intervention was given. This indicates a decrease in BMI results. The results of statistical tests (Wilcoxon test) show ap value: $0.013(\mathrm{p}<0.05)$ means that Ho is rejected, meaning that statistically, there is a significant effect of VCO intervention on BMI reduction in obese people in the work area bontonyeleng puskesmas Conclusion IMT measurement The sample is 30 people. Research Results The results showed that the median in the group given VCO intervention was lower than before VCO intervention was given. This indicates a decrease in BMI results. The results of statistical tests (Wilcoxon test) show ap value: $0.013(p<0.05)$ means that Ho is rejected, meaning that statistically, there is a significant effect of VCO intervention on BMI reduction in obese people in the work area bontonyeleng puskesmas Conclusion IMT measurement showed a significant difference between the treatment group and the control group, the difference was higher in the treatment group. And there is the effect of VCO intervention on reducing BMI in obese people in the working area of the Bontonyeleng Health Center. Which means that if $\mathrm{VCO}$ is effective in reducing a person's body mass index.
\end{abstract}

Keywords: vCO, Obesity, Women.

\section{INTRODUCTION}

Obesity is a condition in which body fat is in excessive amounts [1]. Obesityis a risk factor for the 5th cause of death in the world. About 2.8 million people worldwide die from complications of obesity, $23 \%$ suffer from ischemic heart disease, and $7 \%$ to $41 \%$ have a risk of developing cancer in certain organs [2].

In 2016, WHO explained thatobesity kills more people than people who are malnourished. More than 1.9 billion adults aged 18 years and over are obese among the world's population who live in developing countries, including Indonesia [3].

Copyright (C) 2021 The Author(s): This is an open-access article distributed under the terms of the Creative Commons Attribution 4.0 International License (CC BY-NC 4.0) which permits unrestricted use, distribution, and reproduction in any medium for non-commercial use provided the original author and source are credited. 
The results of the 1996/1997 national survey in the capitals of all provinces in Indonesia $8.1 \%$ of men were classified as obese at $6.8 \%$ while $10.5 \%$ of women were classified as obese at $13.5 \%$ [4].

The prevalence of obesity based on gender in the district / city in (2014), Makassar city as many as 344 people. As many men 114 people and as many as 230 women [5]. Whilein Bulukumba Regency (2016), the prevalence of obesity was 913 people (49.3\%). As many as 115 men (7.21\%), 798 women $(50.03 \%)$ gathered from several health centers. The highest prevalence is in the working area of Puskesmas Bonto Bahari as much as $425(44.6 \%)$ and the lowest is in the working area of Puskesmas Caile 38 people (36.54\%). There are 13 health centers that have not collected data on obesity, one of which is the Bontonyeleng Health Center [6].

Based on the initial survey conducted by enumerators, researchers on housewives in Taccorong Village which is also the working area of Bontonyeleng Health Center (2018), the results of measuring height and weight for 87 housewives found 64 people who were obese and of childbearing age. (15-49) years, 7 people in the obesity category aged over 49 years and 16 people in the overweight category with the number of mothers as many as $1011(52.82 \%)$

Based on the 2013 Riskesdas data, the incidence of prediabetes can be seen from the disturbed fasting blood sugar, which is in the range 100-125 mg / dl. The result of the proportion of population aged $\geq 15$ years with disturbed GDP is found by more women than men with a percentage of $7.7 \%$ and more who live in rural areas than those who live in urban areas, namely, $7.0 \%$.

Most of the patients diagnosed with Diabetes Mellitus, especially type II, are overweight or obese. Obesity occurs due to genetic disposition, too much food intake, and too little physical activity. Conditions such as causing an imbalance between energy supply and expenditure can increase the concentration of fatty acids in the blood. This in turn reduces the use of glucose in muscle and fat tissue. The result is insulin resistance which forces the insulin release to increase. Because the regulatory receptors decrease, insulin resistance increases.

Virgin Coconut Oil (Pure Coconut Oil) is coconut oil with high quality because it contains no cholesterol, only a small amount of water and free fatty acids are present, and the content of soluble acids is quite high (around 53\%). In addition, VCO is the result of fresh "organic" coconut content or in other words it is not a product of "copra" processing. Not using chemicals, high temperature, not partially hydrogenated, nor using any solvent (solvent) to get high yields. Based on the VCO content, it is safe to consume in various ways. One way is to drink it to reduce the value of glucose levels in the blood. Virgiin Coconut Oil is a high quality coconut product that is a mainstay product in coconut producing countries.

Taccorong Village is the working area of the Bontonyeleng Health Center and is also a village assisted by Stikes Panrita Husada Bulukumba so researchers are interested in researching "The effectiveness of VCO (Virgin Coconut Oil for people with obesity in the working area of the Bontonyeleng Community Health Center, Taccorong Village, Gantarang District, Bulukumba Regency ".

\section{METHOD}

This research design uses two groups, by doing one measurement in front (pre-test) before the treatment (treatment) and after that measuring again (post-test). When this research was conducted in October 2020 in the Work Area of the Bontonyeleng Community Health Center, Taccorong Village, Gantarang District, Bulukumba Regency. The population in this study were obese people. The sample is 30 people. This study uses two types of variables, namely the independent variable and the dependent variable. The independent variable (independent) in this study is Virgin Coconut Oil, while the dependent variable (dependent) is the Body Mass Index. The research instrument for the obesity variable was the observation sheet using the scales digital (GEA) and body meter (stature meter / microtoice).

\section{RESULTS}

Based on Table-1, the results of the distribution of the characteristics of respondents in Taccorong Village, the working area of the Bontonyeleng Community Health Center, were 30 people, all of which were female as many as 30 people $(100 \%)$. For job characteristics, there were more than 15 housewives $(65 \%)$, while the lowest was self-employed, namely 1 person $(3.3 \%)$.

Based on the distribution of the body mass index of 30 respondents from two groups, it was found that in the intervention / treatment group of 15 respondents, the mean difference between the pre and post BMI measurements was 0.43. Whereas in the control group of 15 people, the mean difference between the pre and post BMI measurements was 0.09. From these two results, there is a difference by looking at the difference in means that is significantly different, there is a higher difference in the treatment group compared to the control group. 
Table-3 above shows that the median in the group given VCO intervention was lower than before the VCO intervention was given. This indicates a decrease in BMI results. The result of statistical test (Wilcoxon test) shows $\mathrm{p}$ value: $0.013(\mathrm{p}<0.05)$ means Ho is rejected, meaning that statistically it shows that there is a significant effect of VCO intervention on BMI reduction in obese people in the work area of Bontonyeleng Health Center.

Table-1: Distribution of Characteristics of Respondents in Taccorong Village the working area of the Bontonyeleng Community Health Center in Bulukumba Regency in 2020

\begin{tabular}{|l|l|l|}
\hline Characteristics & F & \% \\
\hline Gender & & \\
\hline Women & 30 & 100.0 \\
\hline Profession & & \\
\hline Housewife & 15 & 50.0 \\
\hline Private employees & 2 & 6.7 \\
\hline entrepreneur & 1 & 3.3 \\
\hline College student & 10 & 33.3 \\
\hline Student & 2 & 6.7 \\
\hline Total & 20 & 100.0 \\
\hline
\end{tabular}

Table 2: Distribution of the body mass index of respondents in the working area of the Bontonyeleng Community Health Center 2020

\begin{tabular}{|l|l|l|l|}
\hline \multicolumn{2}{|l|}{ Average (SB) } & Difference Average \\
\hline \multirow{2}{*}{ PRE IMT } & Treatment & $29.16(1.61)$ & Treatment $(0.43)$ \\
\cline { 2 - 4 } & Control & $29.25(4.3)$ & \\
\hline \multirow{2}{*}{ IMT POST } & Treatment & $28.73(1.87)$ & Control $(0.09)$ \\
\cline { 2 - 4 } & Control & $29.16(4.37)$ & \\
\hline
\end{tabular}

Table-3: Analysis of differences in BMI values before and after being given VCO in the working area of the Bontonyeleng Community Health Center

\begin{tabular}{|l|l|l|l|l|}
\hline BMI & Median & Minimum & Maximum & P \\
\hline Pre intervention & 29.16 & 26.69 & 32.40 & 0.013 \\
Post intervention & 28.80 & 25.57 & 32.40 & \\
\hline \multicolumn{4}{|r}{ * Paired T test (Wilcoxon test) } \\
\hline
\end{tabular}

\section{DISCUSSION}

\section{BMI in people with obesity}

Based on the distribution of the body mass index of 30 respondents from two groups, it was found in the intervention / treatment group of 15 respondents that the mean difference in the pre and post BMI measurement results was 0.43 . Whereas in the control group of 15 people, the mean difference between the pre and post BMI measurements was 0.09 . From these two results, there is a difference by looking at the difference in means that is significantly different, there is a higher difference in the treatment group compared to the control group.

Body mass index is a measuring tool used to determine the ideal body weight. Someone who is said to be obese or over weigth is obtained by calculating the body mass index. Overweight and obesity are chronic conditions that are very much associated with a number of degenerative diseases. Body mass index (BMI) is a benchmark for monitoring whether a person's body weight is classified as less than ideal or even overweight. The way to calculate by calculating is to compare the weight $(\mathrm{kg})$ of the body with the height $(\mathrm{cm})$ [7].

Obesity is an increase in body weight that exceeds the limits of physical and skeletal needs as a result of excessive fat accumulation in the body. Obesity not only affects physical health but also has an impact on mental health. The psychological impact caused, for example, individuals feel ashamed, insecure, and feel that other people are disgusted by them [8].

The prevalence of obesity and overweight increased significantly in women and men. Recent studies have shown that abdominal obesity is more likely to be associated with cardiovascular events and other metabolic diseases. a study reported that the inverse relationship between adiponectin and obesity and the risk of type 2 diabetes. Obesity is closely related to the occurrence of type 2 diabetes mellitus [8].

Differences in body mass index in people with obesity before and after being given VCO (Virgin Coconut Oil) 
Based on the results of the study, it was found that the median in the group given VCO intervention was lower than before the VCO intervention was given. This indicates a decrease in BMI results. The result of statistical test (Wilcoxon test) shows p value: 0.013 ( $\mathrm{p}<0.05$ ) means Ho is rejected, meaning that statistically it shows that there is a significant effect of VCO intervention on BMI reduction in obese people in the work area of Bontonyeleng Health Center. The results of this study were significant if VCO was effective in reducing a person's body mass index.

There are several determinants that can be assessed on a person's BMI reduction, a healthy lifestyle that can be seen from indicators of diet and physical activity. Physical activity is one of the factors that can increase energy needs, so that if physical activity is light, the possibility of obesity will increase. Various studies have shown that the length of television viewing habits is associated with an increased prevalence of obesity. Meanwhile, moderate to heavy activities will reduce the possibility of obesity [4].

In this study, it was found that the dominant job is as a housewife (IRT) who spends more time at home compared to doing activities outside the home. According to Proverawati A [9] which affects the occurrence of obesity in a person is physical activity. According to Kopelman in 2000, research in developed countries found a relationship between light physical activity and the incidence of obesity. Individuals with light physical activity have a risk of increasing body weight by $5 \mathrm{~kg}$.

In line with research conducted by Nurul, Santoso \& Utamy [10] with the title of physical activity and the incidence of central obesity in women in Tanah Patah Village, Bengkulu City, using the chis quare test with a value of $\mathrm{p}$ $=0.039<0.05$. So the results show that there is a significant relationship between physical activity and the incidence of obesity.

Researchers argue that the incidence of obesity is caused by unhealthy lifestyles, ranging from diet and physical activity patterns. Physical activity is closely related to especially light physical activity. Physical activity of obese housewives, they do more light physical activity such as cooking, sitting a lot, sleeping, and watching TV. So that they are more at risk of developing degenerative diseases due to obesity because they do not keep up with exercise. Even though it is known that exercise can provide such benefitsincrease the body's metabolism to prevent obesity and maintain an ideal body weight, reduce the risk of various diseases such as high blood pressure, coronary heart disease, diabetes, improve the hormonal system, and increase the immune system against disease

Statistically, there is a difference in body mass index between before and after VCO administration. This can be explained based on the existing theory regarding VCO metabolism in reducing body mass index. Based on the theory of MCT, which is in VCO, after being digested in the digestive tract, it will be directly absorbed through the intestinal wall without going through hydrolysis and enzymatics, then supplied into the bloodstream and directly carried to the liver. In the liver, MCT molecules are processed to produce energy and do not accumulate into fat [11]. VCO can gradually regenerate pancreatic beta cells so that insulin production can be stimulated more and insulin sensitivity is also improved.

\section{Conclusions and Suggestions}

1. The BMI measurement showed a significant difference between the treatment group and the control group, the difference was higher in the treatment group.

2. There is an effect of VCO intervention on reducing BMI in obese people in the working area of the Bontonyeleng Health Center. Which means if VCO is effective in reducing a person's body mass index.

3. Diet and physical activity can be a contributing factor in the increase in BMI in obese people.

\section{REFERENCES}

1. Muriyati., \& Syamsuddin. (2018). Overweight Basics Aerobic Obesity. Babadan Ponorogo East Java Indonesia: Wade Group.

2. Nugroho, K., Mulyadi, N., \& Masi, G. N. M. (2016). Hubungan Aktivitas Fisik Dan Pola Makan Dengan Perubahan Indeks Massa Tubuh Pada Mahasiswa Semester 2 Programstudi Ilmu Keperawatan Fakultas Kedokteran. Jurnal Keperawatan, 4(2).

3. WHO. (2013). A Global Brief on Hyperension. Silent Killer Global public health crisis.

4. Soegih, R., \& Wiramihardja, K. K. (2009). Obesitas Permasalahan Dan Terapi Klinis.

5. Makassar City Health Profile, 2014.

6. Bulukumba Health Office. (2016). Disease Prevention and Management Section.

7. Arisman, A. (2018). Determinant of human development index in ASEAN countries. Signifikan: Jurnal Ilmu Ekonomi, 7(1), 113-122.

8. Hasdiana, H., \& Ayuddin, A. (2017, September). Quality Improvement of Corn Husk as Raw Material for Textile Products. In 1st International Conference on Social, Applied Science and Technology in Home Economics (ICONHOMECS 2017). Atlantis Press. 
9. Proverawati, A., \& Ismawati, C. (2010). BBLR (berat badan lahir rendah). Yogyakarta: Nuha Medika, 61.

10. Santoso, N. I. (2018). Program Sarjana Universitas Muhammadiyah Gresik. Pengaruh Hormon Alami dengan Tingkat Konsentrasi dan Lama Perendaman terhadap Pertumbuhan Stek Batang Tanaman Tin (Ficus carica L.) (Doctoral dissertation, Universitas Muhammadiyah Gresik).

11. Amin, S. (2009). Review on biofuel oil and gas production processes from microalgae. Energy conversion and management, 50(7), 1834-1840.

CITATION: Nadia Alfira et al (2021). The Effectiveness of VCO (Virgin Coconut Oil) in People with Obesity in the Working Area of Public Health Bontonyeleng. South Asian Res J Nurs Health Care, 3(2): 22-26. 